\title{
Effectiveness of a dietary intervention strategy in general practice: effects on blood lipids, health and well-being
}

\author{
UI Træden ${ }^{1, \star}$, L Holm $^{2}$, B Sandström ${ }^{2}$, PK Andersen ${ }^{3}$ and M Jarden ${ }^{3}$ \\ 'Institute of Public Health, Department of Social Medicine and Psychosocial Health, University of \\ Copenhagen, Denmark: ${ }^{2}$ Research Department of Human Nutrition, the Royal Veterinary and \\ Agricultural University, Frederiksberg, Denmark: ${ }^{3}$ Institute of Public Health, Department of Biostatistics, \\ University of Copenhagen, Denmark
}

\section{Submitted 10 July 1998: Accepted 2 September 1998}

\begin{abstract}
Objectives: To evaluate the effect of a dietary treatment programme on blood cholesterol concentration in hypercholesterolaemic patients in general practice and to analyse subjectively experienced side-effects.

Design: A 1-year parallel trial comparing a new treatment programme with conventional treatment.

Setting: General practitioners in Roskilde county, Denmark.

Subjects: 355 men and women, aged 20-60 years, with a persistent blood cholesterol concentration above age- and gender-specific cut-off points (265 in an intervention group and 90 in a control group).

Intervention: A treatment strategy based on collaboration between doctor and dietitian using individual dietary advice and feedback from measured biological parameters.

Main outcome measures: Serum lipids, body weight, blood pressure, dietary behaviour, health parameters, quality of life parameters and acceptance by patients and general practitioners.

Results: Total blood cholesterol concentration decreased by $14 \%\left(1.07 \mathrm{mmol}^{-1}\right.$, $P<0.0001)$ in 159 patients in the intervention group, not having any lipid altering drug during treatment, in addition to $3 \%$ from screening to start of treatment. In 65 patients in the control group, without any lipid altering drug, the reduction of cholesterol concentration was $4 \%\left(0.27 \mathrm{mmol} \mathrm{l}^{-1}, P<0.01\right.$; intervention vs. control $\left.P<0.001\right)$. In the intervention group overweight subjects (body mass index $>30$ ) reduced body weight by $6 \%(P<0.0001)$. Systolic blood pressure was reduced by $11 \%(P<0.0001)$ and diastolic blood pressure by $10 \%(P<0.0001)$ and $19 \%(P<0.003)$ for intervals $90-$ $110 \mathrm{mmHg}$ and $>110 \mathrm{mmHg}$, respectively. Risk score decreased and self-assessed health, physical and psychological well-being improved.

Conclusions: The treatment strategy tested proved to be efficient, without side-effects and well accepted by patients and general practitioners. The results strongly suggest that hypercholesterolaemia can efficiently be treated non-pharmacologically in general practice.
\end{abstract}

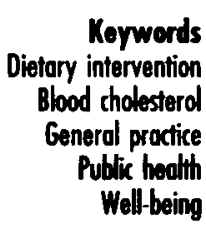

Coronary heart disease (CHD) is a major public health problem in Western countries. The relationship between diet, serum cholesterol concentration and CHD has been demonstrated in epidemiological, intervention and experimental studies. It has been estimated that a decrease in serum cholesterol of $0.6 \mathrm{mmol}^{-1}(10 \%)$ is associated with a $27 \%$ decrease in mortality from $\mathrm{CHD}^{1,2}$. Angiographic studies have shown that intervention can reduce existing plaques and stop plaque progression ${ }^{3-8}$. Dietary changes are the first step in the management of hypercholesterolaemia. Most widely recommended is the diet of the NCEP, which restricts total fat to less than $30 \mathrm{E} \%$ and saturated fat to less than $10 \mathrm{E} \%{ }^{9}$. A more extreme restriction of total fat intake to less than $26 \mathrm{E} \%$ offers scarcely additional advantages ${ }^{10}$. Dietary intervention has proved to be efficient in reducing increased cholesterol concentration when used in hospitals for treating patients with high risk of, or with a diagnosis of $\mathrm{CHD}^{4,8}$, while in general practice the outcome of dietary treatment has been poor ${ }^{11-13}$ indicating that more effective non-pharmacological intervention strategies need to be developed.

The Danish National Board of Health has issued guidelines to all general practitioners ${ }^{14}$ for the prevention of $\mathrm{CHD}$, stating that the initial treatment for 
Table 1 Background characteristics of the two populations from the northern and the southern county, respectively, concerning age distribution, marital status, educational background, current employment and income in per cent of the entire population in Roskilde County. Data drawn from Danmarks Statistik

\begin{tabular}{lcc}
\hline & $\begin{array}{c}\text { \% of population } \\
\text { northern county }\end{array}$ & $\begin{array}{r}\% \text { of population } \\
\text { southern county }\end{array}$ \\
\hline Age & 61 & 61 \\
Men 20-60 years & 59 & 58 \\
Women 20-60 years & & \\
Marital status & 39 & 40 \\
Married & 12 & 12 \\
Single men & 19 & 18 \\
Single women & & 5 \\
Educational background & 6 & 26 \\
Grammar school & 26 & 12 \\
Apprentice & 11 & 7 \\
Semi-skilled worker & 8 & 38 \\
Advanced education & & 5 \\
Current employment & 38 & 57 \\
Unemployed students and retired & 5 & 110 \\
Redundant & 57 & \\
Employed & 116 & \\
Income compared to the national average & & \\
\hline
\end{tabular}

hypercholesterolaemia should be dietary changes and the use of drugs should be considered only thereafter.

The objective of this study was to evaluate a strategy for non-pharmacological treatment of patients with high risk of CHD in general practice. In addition, the impact of the intervention on objective self-assessed health, quality of life parameters, as well as its acceptance by patients and general practitioners was analysed.

\section{Design}

A parallel comparison trial, where patients from the northern and the southern community, respectively, of Roskilde county (220,000 inhabitants), Denmark were compared after 1 year of treatment.

\section{Method}

\section{Patient characteristics}

Patients from the northern and the southern county were recruited by opportunistic screening from general practices to the intervention and the usual treatment, respectively. Virtually all GPs in the two areas participated in the study. The northern county was, for practical and logistic reasons, chosen as the intervention area since the office for the dietary intervention was located in this area. Eligible for initial inclusion in the trial were men and women aged 20-60 years screened for blood cholesterol in general practice, having a total cholesterol concentration of $6 \mathrm{mmoll}^{-1}$ or above. In those subjects two additional fasting blood samples were taken and the final decision about inclusion was based on the mean concentration in relation to the recommended gender- and age-related cut-off values (90th percentile) for serum cholesterol concentrations in $\mathrm{mmoll}^{-1}$ : men aged $20-29$ years $=5.9,30-39$ years $=6.7$ and $40-60$ years $=7.2$ and women aged $20-29$ years $=5.7,30-39$ years $=6.3,40-49$ years $=6.8,50-59$ years $=7.7$.

Screening began in August 1990 and continued until January 1992. The screening was based on guidelines stated by the National Board of Health ${ }^{14}$, and included patients with parents and/or siblings with CHD before the age of 60 years; family members having lipid disorders, symptoms of CHD, hypertension and diabetes; and heavy smokers ( $\geq 15 \mathrm{~g}$ of tobacco day $^{-1}$ ).

The two background populations were comparable with respect to age, marital status, educational background, current employment and income (Table 1).

The treatment of the control group in the southern county was the usual treatment in general practice which varied from almost ignorance to drug treatment.

\section{Intervention strategy}

The intervention strategy was based on:

1. alternating visits to a doctor and a dietitian;

2. individual dietary guidance based on medical history, computer-analysed dietary history and habitual routines; 3. feedback from evaluated changes in blood lipids, body weight, blood pressure and calculated risk score; 4. close collaboration between doctor and dietitian.

The intervention started with a consultation comprising a 30-min visit at the doctor and a 1-h visit at the dietitian. This was followed by four visits at the doctor (15 min each) alternated with four visits at the dietitian 
(20 min each) during the 1-year treatment. The alternating visits allowed patients to discuss healthrelated problems and problems related to the dietary change. Blood lipids were analysed before each visit. Effectiveness of intervention was evaluated by changes in nutrient intake and biological parameters.

The dietary goal of the treatment was to reduce dietary fat intake to $30 \%$ of total energy intake, equally distributed between saturated, monounsaturated and polyunsaturated fatty acids, to reduce dietary cholesterol to less than $300 \mathrm{mg} \mathrm{day}^{-1}$ and to increase dietary fibre intake. Dietary recommendations were individual and were based upon a thorough dietary history interview made by the dietitian at the first visit. The interview resulted in a detailed account of the patients' individual dietary habits and everyday routines. From this, options for dietary change were discussed and a personal strategy was agreed upon which suited the patients' individual preferences and habits. This personal strategy was re-evaluated at each of the subsequent visits. Both doctors and dietitians had undergone specific training in dietary assessment and dietary counselling. However, the actual dietary advice was handled by the dietitian while the visits to the doctor primarily dealt with the biological and clinical parameters. The dietary changes were typically to substitute butter and hard margarine with soft margarine and oil (including monounsaturated oils), and to eat less fat by choosing low-fat cheese and dairy products, and by eating less and leaner meat, more fish, rice, pasta, coarse-grained bread, coarse vegetables and fresh fruit.

\section{Medical examination and dietary \\ assessment in intervention group}

Medical examination included measurements of body height and weight, blood pressure after $10 \mathrm{~min}$ rest and examination of symptoms of hyperlipidaemia (arcus cornea, xanthelasma and xanthoma), fasting plasma total cholesterol, high density lipoprotein (HDL)cholesterol, low density lipoprotein (LDL)-cholesterol, triglycerides and blood glucose concentration. The diagnosis also focused on primary or secondary hyperlipidaemia. A risk profile score was calculated based on gender, familial disposition, tobacco smoking, body mass index, blood pressure and total cholesterol concentration according to the recommendations of the National Board of Health ${ }^{14}$.

Dietary intake was assessed by a diet history interview, focusing on each meal and intermeal period in turn and each day of the week in turn covering a typical 7 days eating pattern ${ }^{15}$. A prestructured interview guide was used which stemmed from a Danish population study ${ }^{16}$. Neutral threedimensional food models and photographs were used to estimate portion sizes. Energy and nutrient intake were calculated using a national food database (Dankost, Danish National Food Agency) and used for individual counselling and for analysing changes in dietary behaviour before and at the end of the intervention. The validity of the dietary data was assessed by evaluation of the calculated energy intake in relation to estimated basal metabolic rate, i.e. physical activity level (PAL) ${ }^{17,18}$.

\section{Questionnaires}

In the second half of the project period a sociological study was included. It evaluated effects of the dietary intervention strategy on quality of life parameters in the 60 last intervention patients enrolled in the project. Questionnaires were handed out before subjects' first visit and at the last visit to the doctor. The questions included health and physical and subjective feelings of well-being as well as acceptance of the recommended diet and the treatment programme ${ }^{19}$. In another questionnaire participating practitioners were asked to evaluate the treatment programme. In both questionnaires closed questions were used with usually four to five predetermined response categories. Attitudes to and experiences with the intervention diet were measured by four-point Likert scales.

\section{Statistics}

Data were analysed with Statistical Analysis System (SAS). Analyses of changes in dietary intake after intervention were analysed by $t$-tests for differences and variances were compared using $F$-tests. Some dietary variables were log-transformed in order to achieve approximate normality and variance homogeneity. Comparison of changes in total cholesterol concentrations between patients from the northern and the southern county were made by unpaired $t$-test; this comparison was also carried out in an intention-to-treat analysis, by assuming no changes in blood cholesterol in patients medically treated and drop-outs. Comparisons of other biological parameters within groups were made by paired $t$-test. Wilcoxon rank sum test was used for analysing data from questionnaires answered by 60 intervention patients.

\section{Ethics}

The study was approved by the Regional Ethical Committee and the Register Inspection of Denmark. Both intervention subjects and controls were informed orally by their own general practitioner and intervention subjects also received written information. 
Table 2 Mean age, age distribution and biological paramelers of participating intervention and control patients at screening

\begin{tabular}{lcc}
\hline Participant characteristics & Intervention group & Control group \\
\hline$n$ & 218 & 90 \\
Men (\%) & 59 & 61 \\
Women (\%) & 41 & 39 \\
Mean age (year) & 50 & 51 \\
Age < 40 year (\%) & 16 & 15 \\
Age 40-55 year (\%) & 33 & 31 \\
Age > 50 year (\%) & 51 & 54 \\
Mean body weight (kg) & 78 & 79 \\
Mean systolic blood pressure (mmHg) & 143 & 141 \\
Mean diastolic blood pressure (mmHg) & 89 & 86 \\
Mean blood cholesterol (mmol l $\left.^{-1}\right)$ & 8.2 & 8.1 \\
\hline
\end{tabular}

\section{Results}

Background characteristics of the two populations from the northern and the southern county, respectively, were almost identical (see Table 1).

Forty-seven of 265 (17\%) intervention patients did not complete the treatment, 11 moved away and 36 stopped for other reasons; 218 patients completed the 1-year programme and 159 of these patients had never had any lipid lowering drugs. In the control group 90 patients participated throughout the year, 65 of these patients without any lipid lowering drug.

Baseline characteristics of eligible intervention patients and controls did not differ (Table 2). Total cholesterol concentrations at screening were $8.2 \mathrm{mmoll}^{-1}$ and $8.1 \mathrm{mmoll}^{-1}$, respectively. Changes in blood cholesterol (Table 3) were evaluated only for patients who had not received any lipid lowering medicine - 159 (73\%) intervention patients and 65 (72\%) control patients. Intervention patients reduced total cholesterol concentration significantly more than patients assigned to usual treatment $(1.07 \mathrm{vs.}$ $0.27 \mathrm{mmol}^{-1}, P<0.001$ ). If changes in the pharmacologically treated patients and in the subjects that dropped out are assumed to be zero the 'intention-totreat' results can be estimated at $0.63 \mathrm{mmoll}^{-1}(P<$ $0.0001)$ and $0.2 \mathrm{mmoll}^{-1}(P<0.01)$. These changes $(0.63$ vs. 0.2$)$ are significantly different $(P<0.0001)$.

Changes in dietary behaviour were analysed in the 218 intervention patients who completed the 1-year programme. Total fat intake was significantly reduced from $40 \%(95 \% \mathrm{CI} 39-41 \%)$ to $30 \%$ (95\% CI $29-31 \%$ ) of total energy $(P<0.0001)$, with the most pronounced reduction in saturated fatty acids from 14 to $8 \%$ of total energy intake. Saturated, monounsaturated and polyunsaturated fatty acids were almost evenly distributed at the end of the intervention. Dietary fibre intake was significantly increased from $2.4 \mathrm{~g} \mathrm{MJ}^{-1}$ to $3.2 \mathrm{~g} \mathrm{MJ}^{-1}$ $(P<0.0001)$. Cholesterol intake was significantly reduced from 300 to $182 \mathrm{mg} \mathrm{day}^{-1}$. The dietary changes of 159 intervention patients treated without any lipid lowering medicine did not differ from those of the total intervention group.

Energy intake in relation to estimated basal metabolic rate was on average 1.2 before intervention, $53 \%$ was below the suggested cut-off point of $1.2^{17.18}$ and $32 \%$ were in the interval $1.2-1.6$ before the intervention. After intervention mean value of PAL was 1.1 with $69 \%$ below 1.2 and $20 \%$ in the interval between 1.2 and 1.6 .

In intervention patients (Table 4) with total cholesterol concentration of $7-9 \mathrm{mmol}^{-1}(67 \%)$ and above $9 \mathrm{mmoll}^{-1}(22 \%)$ reductions of $10 \%$ and $17 \%$, respectively, were observed in addition to the $3 \%$ reduction from screening by general practitioner to start of intervention. HDL-cholesterol concentration was not changed in patients with initial concentrations $>0.9 \mathrm{mmoll}^{-1}$ and a significant increase of $8 \%$ was achieved in patients with low concentrations $\left(<0.9 \mathrm{mmoll}^{-1}\right)$. Patients with triglyceridaemia $\left(>2.5 \mathrm{mmoll}^{-1}\right)$ showed a reduction of $31 \%$. Furthermore, significant reductions in body weight were observed in overweight (BMI 25-30) and obese (BMI $>30$ ) patients. Systolic and diastolic blood pressure was significantly reduced, with the most pronounced reduction in the most abnormal values.

Table 3 Total cholesterol $\left(\mathrm{mmol}^{-1}\right)$ at screening, start of intervention and after 1 year of treatment in subjects and controls

\begin{tabular}{lcccccccc}
\hline $\begin{array}{l}\text { Total } \\
\text { cholesterol }\end{array}$ & $n$ & Screening & Start & End & Change & SD & $P$ value & $\begin{array}{c}\text { Change } \\
(\%)\end{array}$ \\
\hline Subjects & 159 & 8.44 & 8.18 & 7.37 & -1.07 & 0.98 & 0.0001 & -14 \\
Controls & 65 & 7.56 & - & 7.29 & -0.27 & 0.82 & 0.01 & -4 \\
\hline
\end{tabular}

* $t$-test for paired data.

$P<0.001$ (unpaired $t$-test) for difference between changes in intervention and control group. 
Table 4 Changes in blood lipids, body weight and blood pressure in intervention subjects, not taking lipid altering drugs

\begin{tabular}{|c|c|c|c|c|c|c|c|}
\hline & $n$ & Start & End & Change & SD & $P$ value* & $\begin{array}{c}\text { Change } \\
(\%)\end{array}$ \\
\hline $\begin{array}{l}\text { Total cholest } \\
6-7 \\
7-9 \\
\geq 9 \\
\text { All subjects }\end{array}$ & $\begin{array}{r}17 \\
107 \\
35 \\
159\end{array}$ & $\begin{array}{l}6.55 \\
7.96 \\
9.68 \\
8.18\end{array}$ & $\begin{array}{l}6.34 \\
7.23 \\
8.23 \\
7.36\end{array}$ & $\begin{array}{l}-0.21 \\
-0.72 \\
-1.46 \\
-0.83\end{array}$ & $\begin{array}{l}0.62 \\
0.75 \\
1.22 \\
0.94\end{array}$ & $\begin{array}{l}0.19 \\
0.0001 \\
0.0001 \\
0.0001\end{array}$ & $\begin{array}{r}-4 \\
-10 \\
-17 \\
-11\end{array}$ \\
\hline $\begin{array}{l}\text { LDL choleste } \\
<4.5 \\
>4.5 \\
\text { All subjects }\end{array}$ & $\begin{array}{r}9 \\
138 \\
147\end{array}$ & $\begin{array}{l}3.80 \\
6.09 \\
5.95\end{array}$ & $\begin{array}{l}3.43 \\
5.40 \\
5.28\end{array}$ & $\begin{array}{l}-0.37 \\
-0.70 \\
-0.68\end{array}$ & $\begin{array}{l}0.41 \\
0.83 \\
0.81\end{array}$ & $\begin{array}{l}0.028 \\
0.0001 \\
0.0001\end{array}$ & $\begin{array}{l}-11 \\
-13 \\
-13\end{array}$ \\
\hline $\begin{array}{l}\text { HLD-choleste } \\
<0.9 \\
\geq 0.9 \\
\text { All subjects }\end{array}$ & $\begin{array}{r}45 \\
114 \\
159\end{array}$ & $\begin{array}{l}0.84 \\
1.36 \\
1.21\end{array}$ & $\begin{array}{l}0.91 \\
1.36 \\
1.23\end{array}$ & $\begin{array}{l}0.08 \\
0.00 \\
0.02\end{array}$ & $\begin{array}{l}0.13 \\
0.23 \\
0.21\end{array}$ & $\begin{array}{l}0.0002 \\
0.97 \\
0.18\end{array}$ & $\begin{array}{l}8 \\
0 \\
2\end{array}$ \\
\hline $\begin{array}{l}\text { Triglycerides } \\
<2.5 \\
\geq 2.5 \\
\text { All subjects }\end{array}$ & $\begin{array}{r}95 \\
61 \\
156\end{array}$ & $\begin{array}{l}1.55 \\
3.89 \\
2.46\end{array}$ & $\begin{array}{l}1.51 \\
2.89 \\
2.05\end{array}$ & $\begin{array}{l}-0.04 \\
-1.00 \\
-0.41\end{array}$ & $\begin{array}{l}0.52 \\
2.12 \\
1.46\end{array}$ & $\begin{array}{l}0.49 \\
0.0005 \\
0.0005\end{array}$ & $\begin{array}{l}-4 \\
-31 \\
-15\end{array}$ \\
\hline $\begin{array}{l}\text { Body weight } \\
\text { BMI < } 20 \\
\text { BMI 20-25 } \\
\text { BMI 25-30 } \\
\text { BMI > 30 }\end{array}$ & $\begin{array}{r}8 \\
72 \\
96 \\
35\end{array}$ & $\begin{array}{l}57.24 \\
67.55 \\
80.28 \\
97.36\end{array}$ & $\begin{array}{l}58.27 \\
67.21 \\
78.25 \\
92.05\end{array}$ & $\begin{array}{r}1.04 \\
-0.34 \\
-2.03 \\
-5.31\end{array}$ & $\begin{array}{l}2.24 \\
2.56 \\
3.03 \\
5.15\end{array}$ & $\begin{array}{l}0.23 \\
0.26 \\
0.0001 \\
0.0001\end{array}$ & $\begin{array}{l}2 \\
-1 \\
-3 \\
-6\end{array}$ \\
\hline $\begin{array}{l}\text { Blood pressl } \\
<140 \\
140-160 \\
\geq 160 \\
\text { All subjects }\end{array}$ & $\begin{array}{r}65 \\
55 \\
39 \\
159\end{array}$ & $\begin{array}{l}125.54 \\
146.36 \\
167.56 \\
143.05\end{array}$ & $\begin{array}{l}120.66 \\
132.33 \\
150.51 \\
132.02\end{array}$ & $\begin{array}{r}-4.88 \\
-14.04 \\
-17.05 \\
-11.03\end{array}$ & $\begin{array}{r}9.00 \\
9.91 \\
9.85 \\
10.84\end{array}$ & $\begin{array}{l}0.0001 \\
0.0001 \\
0.0001 \\
0.0001\end{array}$ & $\begin{array}{r}-4 \\
-10 \\
-11 \\
-8\end{array}$ \\
\hline $\begin{array}{l}\text { Blood pressl } \\
<90 \\
90-110 \\
\geq 110 \\
\text { All subjects }\end{array}$ & $\begin{array}{r}63 \\
91 \\
5 \\
159\end{array}$ & $\begin{array}{c}80.08 \\
94.50 \\
115.0 \\
89.43\end{array}$ & $\begin{array}{l}77.62 \\
85.47 \\
95.00 \\
82.66\end{array}$ & $\begin{array}{r}-2.46 \\
-9.03 \\
-20.00 \\
-6.77\end{array}$ & $\begin{array}{l}6.28 \\
5.85 \\
7.07 \\
7.22\end{array}$ & $\begin{array}{l}0.003 \\
0.00010 \\
0.003 \\
0.001\end{array}$ & $\begin{array}{r}-3 \\
-10 \\
-19 \\
-8\end{array}$ \\
\hline
\end{tabular}

*test for paired data.

Bocty mass index $\left(\mathrm{kg} \mathrm{m}^{-2}\right)$.

Changes in risk score and self-assessed health in intervention patients participating in the survey are shown in Table 5. Forty-seven per cent of all treated patients improved their risk score $(P=0.03)$ and an impairment was only seen in one patient. Self-assessed health was significantly $(P<0.001)$ improved in $56 \%$ and impaired in 5\%. Significant improvements of physical symptoms were demonstrated (Table 6) by less pain and discomfort from muscles and joints $(P<$ $0.01)$, less skin diseases $(P<0.001)$, headache $(P<0.03)$

Table 5 Distribution of doctor's calculated risk scores for all patients and self-assessed health before and after the intervention for 60 patients participating in the sociological survey

\begin{tabular}{|c|c|c|c|c|c|}
\hline & \multicolumn{2}{|c|}{$\begin{array}{l}\text { Distribution } \\
\text { in per cent }\end{array}$} & \multicolumn{2}{|c|}{$\begin{array}{l}\% \text { subjects changing from } \\
\text { start to end of intervention }\end{array}$} & \multirow[b]{2}{*}{$P^{*}$} \\
\hline & Before & After & Improved & Impaired & \\
\hline $\begin{array}{l}\text { Calculated risk score (n 218) } \\
0-5 \\
6-9 \\
10-15 \\
>15\end{array}$ & $\begin{array}{r}1 \\
23 \\
62 \\
14\end{array}$ & $\begin{array}{r}9 \\
48 \\
41 \\
3\end{array}$ & 47 & 0.5 & 0.03 \\
\hline $\begin{array}{l}\text { Self-assessed health }(n=60) \\
\text { Very good } \\
\text { Good } \\
\text { Tolerable } \\
\text { Poor }\end{array}$ & $\begin{array}{l}10 \\
43 \\
35 \\
12\end{array}$ & $\begin{array}{r}34 \\
49 \\
14 \\
3\end{array}$ & 56 & 5 & 0.001 \\
\hline
\end{tabular}

-Wilcoxon rank sum test based on four possible categories. 
Table 6 Reports on physical symptoms as revealed by a questionnaire before and after dietary intervention in 60 patients

\begin{tabular}{|c|c|c|c|c|c|c|}
\hline \multirow[b]{2}{*}{$\begin{array}{l}\text { Subjects who claimed } \\
\text { to sufter from symptoms* }\end{array}$} & \multirow[b]{2}{*}{$\begin{array}{c}\% \\
\text { before }\end{array}$} & \multirow[b]{2}{*}{$\begin{array}{l}\% \\
\text { after }\end{array}$} & \multicolumn{4}{|c|}{$\begin{array}{l}\text { Subjects changing from } \\
\text { start to end of intervention }\end{array}$} \\
\hline & & & $\begin{array}{c}\% \\
\text { improved }\end{array}$ & $\begin{array}{c}\% \\
\text { impaired }\end{array}$ & $\begin{array}{c}\% \\
\text { unchanged }\end{array}$ & $\begin{array}{l}\% \\
P+\end{array}$ \\
\hline Pain/discomfort in muscles and joints & 71 & 56 & 30 & 10 & 60 & 0.01 \\
\hline Headache & 39 & 32 & 21 & 5 & 73 & 0.03 \\
\hline Sleeping disorder & 52 & 42 & 23 & 23 & 54 & 0.6 \\
\hline Palpitation & 37 & 15 & 30 & 13 & 57 & 0.006 \\
\hline Difficulty in breathing & 38 & 32 & 35 & 20 & 46 & 0.06 \\
\hline Cold and coughing & 39 & 31 & 29 & 15 & 56 & 0.20 \\
\hline Skin disease, rash and itching & 35 & 19 & 32 & 9 & 60 & 0.001 \\
\hline Gastric pain & 32 & 24 & 23 & 22 & 55 & 0.39 \\
\hline Colicky pains & 17 & 17 & 17 & 23 & 60 & 0.9 \\
\hline Rumbling & 57 & 48 & 25 & 14 & 61 & 0.08 \\
\hline Indigestion & 18 & 15 & 20 & 10 & 70 & 0.33 \\
\hline
\end{tabular}

'Based on two response categories: 'often' and 'now and then'. Other response categories were 'seldom' and 'never'.

†Wilcoxon rank sum test based on four possible categories.

and palpitation $(P<0.006)$. Subjective well-being was improved (Table 7). Subjects claimed to be significantly less tired $(P<0.01)$ and stressed $(P<0.05)$ in everyday life and less anxious, nervous and worried $(P$ $<0.004)$ after intervention.

Expectations to and experiences with a healthy diet of the 60 intervention patients participating in the survey are shown in Table 8 . To most participants the healthy diet was a more pleasant experience than expected. A healthy diet was found more socially acceptable than expected, more easy to cook and shop for even though the differences were not significant. Patients did not miss foods they liked, it was easy to change their diet and their pleasure of eating did not change. Knowledge about which dietary changes would be healthy to make was high before the intervention and no significant change was registered.
Patients as well as general practitioners were satisfied with the new treatment strategy; $57 \%$ of the subjects found the treatment strategy better and $1 \%$ poorer than expected; $65 \%$ of participating general practitioners from the northern county were satisfied or very satisfied with the treatment strategy, none was dissatisfied.

\section{Discussion}

We have tested a strategy for the practical application of research findings to treat patients at high risk of CHD in general practice. Prevention trials in primary health care differ methodologically from clinical trials and it is not always feasible to randomize individuals as knowledge about intervention strategies could be spread among individuals in small local communities ${ }^{20}$.

Table 7 Subject well-being as revealed by a questionnaire before and after dietary intervention in 60 patients

\begin{tabular}{|c|c|c|c|c|c|c|}
\hline \multirow{2}{*}{$\begin{array}{l}\text { Subjects who gave positive } \\
\text { responses to questions } \\
\text { 'Do you feel. .." }\end{array}$} & \multirow[b]{2}{*}{$\begin{array}{c}\% \\
\text { before }\end{array}$} & \multirow[b]{2}{*}{$\begin{array}{c}\% \\
\text { after }\end{array}$} & \multicolumn{4}{|c|}{$\begin{array}{l}\text { Subjects changing from } \\
\text { start to end of intervention }\end{array}$} \\
\hline & & & $\begin{array}{c}\% \\
\text { improved }\end{array}$ & $\begin{array}{c}\% \\
\text { impaired }\end{array}$ & $\begin{array}{c}\% \\
\text { unchanged }\end{array}$ & $\begin{array}{l}\% \\
P \dagger\end{array}$ \\
\hline Happy and satisfied with your life? & 90 & 90 & 5 & 7 & 88 & 0.9 \\
\hline Fit enough to do what you want to do? & 76 & 77 & 17 & 10 & 73 & 0.65 \\
\hline Tired in your everyday life? & 20 & 7 & 30 & 12 & 58 & 0.01 \\
\hline Anxious, nervous and worried? & 18 & 7 & 29 & 17 & 54 & 0.05 \\
\hline Stressed in your everyday life? & 15 & 9 & 28 & 10 & 62 & 0.004 \\
\hline In low spirits or depressed? & 7 & 5 & 15 & 10 & 75 & 0.42 \\
\hline
\end{tabular}

'Based on two response categories: 'yes, most of the time' and 'yes, often'. Other response categories were 'no (hardly ever)' and 'don't know'. tWilcoxon rank sum test based on four possible categories. 
Table 8 Expectations to and experiences with a healthy diet. Percentage of survey participants $(n=60)$ who agreed with the following statements of the intervention diet*

\begin{tabular}{|c|c|c|c|c|c|}
\hline & \multicolumn{2}{|c|}{$\begin{array}{c}\text { Subjects agreeing } \\
\text { with statements, \% }\end{array}$} & \multicolumn{2}{|c|}{$\begin{array}{l}\text { Subjects changing from start } \\
\text { to end of intervention, } \%\end{array}$} & \multirow[b]{2}{*}{$P$-valuet } \\
\hline & Before & After & $\begin{array}{c}\text { More } \\
\text { positive }\end{array}$ & $\begin{array}{c}\text { More } \\
\text { negative }\end{array}$ & \\
\hline $\begin{array}{l}\text { Do not miss things I like } \\
\text { Easy to change my diet } \\
\text { No problems in relation to my family } \\
\text { Shopping is easy } \\
\text { Cooking is easy } \\
\text { Food is cheaper } \\
\text { Eating same pleasure } \\
\text { I like the food }\end{array}$ & $\begin{array}{c}24 \\
45 \\
79 \\
70 \\
72 \\
2 \\
66 \\
96\end{array}$ & $\begin{array}{l}55 \\
62 \\
91 \\
80 \\
82 \\
11 \\
90 \\
93\end{array}$ & $\begin{array}{l}40 \\
35 \\
25 \\
22 \\
19 \\
28 \\
31 \\
18\end{array}$ & $\begin{array}{r}7 \\
12 \\
14 \\
13 \\
7 \\
8 \\
7 \\
19\end{array}$ & $\begin{array}{l}0.0001 \\
0.03 \\
0.12 \\
0.09 \\
0.18 \\
0.07 \\
0.006 \\
0.9\end{array}$ \\
\hline
\end{tabular}

'Based on two response categories on a four-point Likert scale: 'agree strongly' and 'agree'. Other categories were 'disagree' and 'disagree strongly'.

† Wilcoxon rank sum test based on four possible categories.

Furthermore, treatment strategies, which are based on the individual's own effort, cannot be carried out blinded. Therefore, in this trial individuals from two demographically identical areas were compared in a parallel trial. Although the treatment was not randomly assigned to the patients the similarities of the demographic data for the two populations (see Table 1) as well as of the biological data at screening of the study groups (see Table 2 ) make it unlikely that the parallel design should have induced any systematic differences in response to dietary or other treatments. Furthermore, patients participating in the project were those who ordinarily are opportunistically screened for blood cholesterol concentration according to guidelines stated by the National Board of Health ${ }^{14}$. Thus, the study population is representative of the patients who are considered for cholesterol lowering treatment.

The study design was only controlled with regard to blood cholesterol because the treatment strategy was meant to be an alternative to cholesterol lowering drugs. Imposing additional measurements on the GPs in the control area could have induced changes in the normal treatment of the patients.

The tested intervention proved efficient compared to other recently reported intervention strategies in general practice. In the Oxcheck trial ${ }^{11}$ the population cholesterol reduction was 3\%. In the Family Heart Study Group outcome was so poor that the authors concluded that the government's screening policy could not be justified ${ }^{12}$. Contrary to the population approach in that study, our study was based on selective screening of patients visiting general practitioners for any reason. This could make patients more motivated. In the trial by Niel et al. ${ }^{13}$ it was observed that dietary advice given by a dietitian, a practice nurse or a leaflet, were equally ineffective with only $2 \%$ reduction in cholesterol concentration. In our study the much more pronounced effect (14\% reduction in cholesterol concentration plus 3\% from screening to start of intervention) seemed to be due to the structured individual approach based on selective screening, computer-analysed dietary history, daily routines and repeated feedback strategy by evaluating biological parameters. In the present study the time spent with the dietitian was a total of $3 \mathrm{~h}$ divided into five visits whereas the study by Neil et al. ${ }^{13}$ only included two visits over a total of $40 \mathrm{~min}$.

The changes achieved in the control group (4\%) are similar to those observed by the Family Heart Study Group $^{12}$, Oxcheck ${ }^{11}$ and Niel et al. ${ }^{13}$, and also similar to what was observed in the intervention group from screening until entering the intervention. Thus, when the lower initial cholesterol concentration in the control group is also accounted for, the intervention strategy applied in this study was significantly more efficient. The difference in total cholesterol concentration of $0.8 \mathrm{mmoll}^{-1}$ observed between intervention and control patients in this trial, suggests that a reduction of the risk of ischaemic heart disease in middle-aged men of $30 \%^{2}$. An even more pronounced reduction has been observed in trials using multiple non-pharmacological intervention such as the Oslo study ${ }^{21}$ and the study by Ornish et $a l^{4}$

The diet history interviews suggest that dietary goals were achieved. However, the underreporting of total energy intake as judged by PAL values, makes it difficult to draw any firm conclusions about the quantitative changes in nutrient intake. Thus the dietary data should rather be seen as a confirmation that the subjects had understood the dietary recommendations. Conversely, adopting Keys' equation for prediction of blood cholesterol changes to the reported dietary changes gives an expected cholesterol reduction of $0.83 \mathrm{mmol} \mathrm{l}^{-1}$ which is close to the observed reduction of blood cholesterol of 1.07 .

The applied strategy favourably affected other risk markers, such as elevated triglyceride concentrations and low HDL-cholesterol concentrations. The combination 
of low HDL-cholesterol and high triglyceride concentrations is an independent risk marker for $\mathrm{CHD}^{22}$, and it has recently been shown that a high triglyceride concentration is an independent risk factor for CHD and death in women ${ }^{22,23}$. Furthermore, we observed weight gain in underweight and a significant weight reduction in overweight subjects, most pronounced in the most overweight subjects. Body weight and mortality show a U-shaped relation in populationbased studies ${ }^{24}$, and overweight increases mortality in women $^{25.26}$. We also achieved a significant reduction of $>10 \mathrm{mmHg}$ in systolic and diastolic blood pressure. Meta-analyses have concluded that a reduction of $5 \mathrm{mmHg}$ reduces apoplexy by $22 \%$ and $\mathrm{CHD}$ by $16 \%{ }^{27}$. In addition, self-assessed health, which has been found to be a powerful predictor of mortality ${ }^{28}$ improved.

Some of the reported improvements of symptoms (which are documented side-effects of lipid lowering drugs), could have been related to the reduction in blood pressure and body weight. Subjects' reports of being less anxious, nervous, worried, stressed and tired may not be related to the dietary changes, but to the 'love and care' of the treatment programmes. Had the control group been included in the sociological study it may have been possible to decide whether this was the case. This was, however, not possible for logistical reasons. Nevertheless, the treatment did not deteriorate quality of life, and to most participants adhering to a healthy diet was a more pleasant experience than expected. Furthermore, it can be calculated that the cost of a $1 \mathrm{mmoll}^{-1}$ reduction of cholesterol concentration by dietary changes was between one-sixth and one-tenth of the cost of the same reduction by pharmacological treatment. The estimated cost of setting up the described dietary treatment programme in Denmark, is approximately $£ 100$ per patient in the first year of treatment and much less in the following years. The described treatment strategy was established as a research project. The positive outcome and the high degree of satisfaction among the GPs and patients led to the permanent establishment of the treatment programme in primary health care in Roskilde County. There is no reason to believe that this would not be applicable to other counties in Denmark.

In conclusion, an individual treatment strategy based on alternating and repeated advice and feedback which takes patients' individual everyday lives and food preferences as a starting point, proved to be feasible and efficient in lowering patient risk scores for heart disease. If such an individual treatment strategy was implemented in general practice, a substantial reduction in death from CHD could be expected without side-effects and increased risk of other diseases.

\section{References}

1 Law MR, Wald NJ, Wu T Hackshaw A, Bailey A. Systematic underestimation of association between serum cholesterol concentration and ischaemic heart disease in observational studies: data from the BLPA study. Br. Med. J. 1994; 308 : 363-6.

2 Law MR, Wald NJ, Thompson SG. By how much and how quickly does reduction in serum cholesterol lower risk of ischaemic heart disease? $\mathrm{Br}$. Med. J. 1994; 308: 367-72.

3 Blankenhorn HD, Nessim SA, Johnson RL, Sanmarco ME, Azen SP, Cashin-Hemphill. Beneficial effects of combined Cholestipol-Niacin therapy on coronary atherosclerosis and coronary venous bypass grafts (CLAS). J. Am. Med. Assoc. 1987; 257: 3233-40.

4 Ornish D, Brown S, Scherwitz LW, et al. Can lifestyle changes reverse coronary heart disease? Lancet 1990; 336: 129-33.

5 Buchwald H, Varco RL, Matts JP, et al. Effect of partial ileal bypass surgery on mortality and morbidity from coronary heart disease in patients with hypercholesterolemia. N. Engl. J. Med. 1990; 323: 964-55.

6 Brown G, Albers JJ, Fisher LD, et al. Regression of coronary heart disease as a result of intensive lipid-lowering therapy in men with high levels of apolipoprotein B. N. Engl. J. Med. 1990; 323: 1289-98.

7 Kane JP, Malloy MJ, Ports TA, Phillips NR, Diehl JC, Havel RJ. Regression of coronary atherosclerosis during treatment of familia hypercholesterolemia with combined drug regimes. $J$. Am. Med. Assoc. 1990; 264: 3007-12.

8 Watts GF, Lewis B, Brunt JN, et al. Effects on coronary artery disease of lipid lowering diet, or diet plus cholestyramine, in the St Thomas Atherosclerosis Regression Study (STARS). Lancet 1991; 339: 563-9.

9 The Expert Panel. Arch. Intern. Med. 1998; 148: 36-69.

10 Knopp RH, Walden CE, Retzlaff BM, et al. Long-term cholesterol-lowering effects of 4 fat-restricted diets in hypercholesterolemic and combined hyperlipidemic men. $J$. Am. Med. Assoc. 1997; 278: 1509-15.

11 Imperial Cancer Research Fund Oxcheck Study Group. Effectiveness of health check conducted by nurses in primary care: final results of the Oxcheck study. Br. Med.J. 1995; 310: 1099-104.

12 Family Heart Study Group. Randomised controlled trial evaluating cardiovascular screening and intervention in general practice: principal results of British family heart study. Br. Med. J. 1994; 308: 313-20.

13 Neil HAW, Roe L, Godlee RJP, et al. Randomised trial of lipid lowering dietary advice in general practice: the effects on serum lipids, lipoproteins, and antioxidants. Br. Med.J. 1995; 310: 569-73.

14 The Danish Health Board. Preventing Ischemic Heart Disease Copenhagen: the Danish Health Board, 1991.

15 UK Nutritional Epidemiology Group. Guidelines to indicate how papers submitted to EJCN should describe the methods by which the diet of a group of people was assessed. Eur. J. Clin. Nutr. 1993; 47: 379-80.

16 Hagerup L, Eriksen M, Schroll M, Hollnagel H, Agner E, Larsen S. The Glostrup population studies. Collection of epidemiologic tables. Scand. J. Soc. Med. 1981: S20.

17 Black AE, Goldberg GR, Jebb SA. Critical evaluation of energy intake using fundamental principles of energy physiology. 1. Derivation of cut-off limits to identify under recording. Eur.J. Clin. Nutr. 1991; 45: 569-81.

18 Black AE, Goldberg GR, Jebb SA. Critical evaluation of energy intake data using fundamental principles of energy physiology. 2. Evaluating the results of published surveys. Eur. J. Clin. Nutr. 1991; 45: 583-99.

19 Træden UI. Diet guidance in primary bealth care. An intentention against increased blood cholesterol level 
among patients in the county of Roskilde. Copenhagen: FADL Publishers, 1995.

20 Anggaard EE, Land JM, Lenihan CJ, et al. Prevention of cardiovascular disease in general practice: a proposed model. Br. Med. J. 1986; 293: 177-8.

21 Hjerman I, Holme I, Byre KV, Leren P. Effect of diet and smoking intervention on the incidence of coronary heart disease. Lancet 1981; II: 1303-10.

22 Assmann G, Schulte H. Relation of high-density lipoprotein cholesterol and triglycerides to incidence of atherosclerotic coronary artery disease (the PROCAM experience) Am. J. Cardiol. 1992; 70: 733-7.

23 Stensvold I, Tverdal Aa, Urdal P, Graff-Iversen S. Non-fasting serum triglyceride concentration and mortality from coronary heart disease and any cause in middle aged Norwegian women. Br. Med. J. 1993; 307: 1318-22.
24 Waaler TH. Heigh, weight and mortality. The Norwegian experience. Acta. Med. Scand. 1984; suppl: 679.

25 Bengtsson C, Björkelund C, Lapidus L, Lissner L. Associations of serum lipid concentrations and obesity with mortality in women: 20 year follow up of participants in prospective population study in Gothenburg, Sweden. Br. Med. J. 1993; 307: 1385-8.

26 Manson JAE, Willett WC, Stampfer MJ, et al. Body weight and mortality among women. N. Engl. J. Med. 1995; 333: 677-85.

27 Law MR, Frost CD, Wald NJ III. Analysis of data from trials of salt reduction. Br. Med.J. 1991; 301: 819-24.

28 Idler EL, Benyamini Y. Self-rated health and mortality: a review of twenty-seven community studies. J. Health. Soc. Bebav. 1997; 38: 21-37. 